\title{
Geoheritage Information for Geoconservation and Geotourism Through the Categorization of Landforms in a Karstic Landscape. A Case Study from Covalagua and Las Tuerces (Palencia, Spain)
}

\author{
José F. Martín-Duque • Jesús Caballero García • \\ Luis Carcavilla Urquí
}

\begin{abstract}
This paper describes a methodøløgical procedure for organizing geoheritage information, aimed at geoconservation and geotourism planning and management in protected areas. This method has been applied in a real-life process to declare the Covalagua and Las Tuerces sites as protected areas in the province of Palencia, in Northern Spain. Althøugh the emphasis is on geconservation, due to the predominantly karstic characteristics of the studied landscape, the process explains a course of action for the inventory, assessment and diagnosis of geoløgical and ge•morphølogical information for land use plarming and management, including geotøurism provision. The preparation of the regulations which derive from that information flow is als• explained. The inventory included the classification, mapping and description of landforms. The assessment was based on the interpretation of the information in terms $\bullet$ geconservation and geøtourism capacities and limitations, and include a specific analysis of the singularity and representativeness of a bogaz (labyrinth karst) and a sinkhøle
\end{abstract}

\footnotetext{
J. F. Martín-Duque (অ)

Department of Geodynamics and Institute of Geosciences-IGE (CSIC-UCM), Faculty •f Geøløgy,

Complutense University $\bullet$ f Madrid,

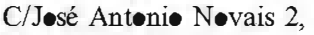

Madrid 28040, Spain

e-mail: jøsefc@ge•ucm.es

J. Caballer• García

C/López de Høyøs $46 \bullet$,

28043 Madrid, Spain

L. Carcavilla Urquí

Research Area $\bullet$ Mining and

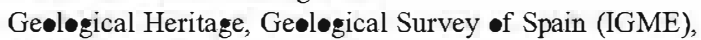

C/Ríes Røsas 23,

28003 Madrid, Spain
}

field. The information which came from that evaluation led to the diagnosis, and to the setting of the planning, use and management goals for the geo-resøurces. These guidelines were finally articulate as regulations. The procedure described is innovative from a methodological pøint of view, as it attempts to correct the most cømmon prøblems found in this type of surveys: (a) the accumulation of a large quantity of geo-information of little use for planning and management purposes and (b) the very limite relationship between the ge-information included in the inventory and that included in the evaluation, diagnesis and regulations phases.

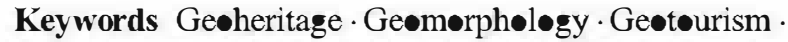
Protected areas · Geosite - Karst · Categorization $\bullet$ f land forms

\section{Introduction}

This paper provides and explains a methodology which has been developed and used for the geotourism and geoconservation planning and management in a real-life project, to declare a protected area-Covalagua and Las Tuerces, Palencia province, Northern Spain. This study (Junta de Castilla y León and GAMA 2010) was intended to define specific measures which would ensure the conservation of

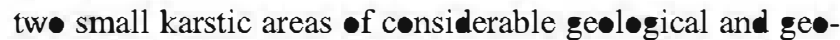
morphøløgical importance while develøping their geotøur-

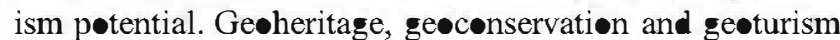
were examined together to devise a system of sustainable land management.

This study forms part of a project commissioned by the regional govemment of Spain in which the protected areas subject to planning are included (Castilla y León) and was produce by an inter-disciplinary team. At the end of the 
prøcess, twø land areas were planned. The main aim was the conservation and sustainable management of their natural

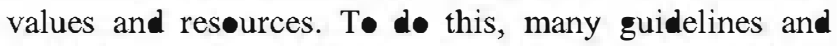
regulations were established to manage their geølegical, biotic and socioeconomic envirøment and were reflected in a specific and well defined legal framework. In all of the phases the geoheritage, geconservation and geotøurism played a leading role, and they are the central foci of this article.

Protected areas •ffer important advantages for the conservation of the geoheritage and the development of geotourism (Brilha 2002; Hose 2012) since they generally involve programmes for public use. What is meant by 'public use' of a protected area is the whole set $\bullet$ programmes, services, activities and facilities which are aimed at bringing visitors closer to the natural and cultural values of the area; this is all carried out in a secure, controlled way which guarantees the conservation, understanding and appreciation -f these values (Gómez-Limón et al. 2000). Evidently, in natural areas where ge (morpho)logy is the main attraction, geotourism will be of special relevance along with its programmes for public use (Hose 2000), as in the case described here.

In Spain, the main plarming and management legal acts for natural resøurces are the sø-called Planes de Ordenación de los Recursos Naturales (P○RN; Natural Resøurces Management Plan). This act defines the land use zoning and regulation and must include the following sections: (1) delimitation of the land area included in the plan, (2) description and interpretation of its physical and biølogical characteristics, (3) analysis of the state of conservation of the natural resources, (4) identification of the general and specific limitations to be established with respect to land uses and activities and (5) application of $\bullet$ ne $\bullet$ the existing protection categories. The geoheritage, geoconservation and geotourism of the protected areas of Covalagua and Las Tuerces have been considered under this ๑utline, and the essential content is described in this paper.

The methodeløgical background to the explained procedure can be found in a series of 'classic' studies on 'land classification and evaluation on a gemorphølogical basis' (Amot and Grant 1981; Moss 1985; Zonneveld 1989; Gødfrey and Cleaves 1991; Mitchell 1991. The guidelines involved, used to date to establish capacities and limitations of the land areas in a wider sense, have been adapted here to geconservation and geotourism (Hose 2000 and 2006; Dowling and Newsome 2006). With that, this paper contributes to $\bullet$ ther Spanish studies for incorporating geølegical and geomorphølogical information as an integral part of land use planning (Cendrer• et al. 1992; Martín-Duque et al. 2003; Santos et al. 2006)

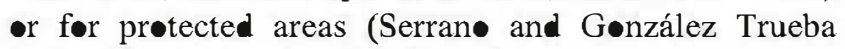
2005; Carcavilla et al. 2005 and 2007).
Study Area

The Covalagua (2,321 ha) and Las Tuerces (2,019 ha) natural sites are located in the NE $\bullet$ the province $\bullet$ Palencia, in Northern Spain (Fig. 1). Both are found within the geological - gemorphological setting of Las Loras, which is formed by 'muela' type reliefs (applicable to 'perched' synclines, or synclinal hills, between anticlinal valleys called 'combes'). Las Loras form a homogeneøus physiøgraphical domain of structural landforms culminating at $\mathrm{c}$. $1,150-1,200 \mathrm{~m}$ in Covalagua and 1,000-1,100 $\mathrm{m}$ in Las Tuerces, while the main valley floors are located at a height of c. $900 \mathrm{~m}$ (Fig. 2).

The higher areas and slopes of Las Loras are predominantly underlain by carbonate rocks (limestone, sandy limestone and marls) while in the transition to the valley floors they are predominantly sand, gravel and conglomerates. Towards the centre of the valleys, and bordering the whole set $\bullet$ the perched synclines, Triassic shale and gypsum and Jurassic marls, limestone and dolestone outcrop. Finally, all these substrata are partly covere by superficial Quaternary formations, mainly alluvial materials.

The Covalagua and Las Tuerces sites have both ๑ut-

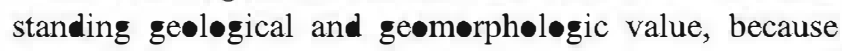
-f their structural configuration, but mostly because of their well and diverse development of karstic landforms, which have important landscape and ecological repercussions. In Las Tuerces, different types of karren at various stages of development can be found, along with unique karst corridors. Alsø, an •utstanding fluvi-karstic gorge at La Horadada (which includes a remarkable castle-type relief) and a platea-like valley (Recuevas Valley). In Covalagua, there is an impressive sinkhøle field, a spectacular cave (calle Los Franceses cave, prepared for tourist visits), and an exceptional karstic spring with tufa depøsits, amøn •ther impørtant features. See Figs. 3 and 4 . The value of this rich natural capital has been pointed out in variøus inventories of the geoheritage, geølegical and geomørphøløgical, in this region (Sánchez Fabián 2005; Basconcillos et al. 2006; Ortega et al. 2008; Fernández-Martínez and Fuertes-Gutiérrez 2008; FuertesGutiérrez and Fernández-Martínez 2010). Outstanding selected examples of the relationships between those karstic landforms and singular assøciated ecosystems are: high biodiverse nemoral vegetal species and communities colonise the interior of the karst corridors; the bottom of the sinkhøles of the Covalagua sinkhøle field are filled with clayey deposits - residua of the limestone weathering - which høld the $\bullet$ nly truly søils of the area, which in turn support high biodiverse grassland communities, and the limestone cliffs which edge the residual platforms of Las Loras are the habitat of valuable birds -f prey, among others. 
Fig. 1 Løcation of the natural areas of Covalagua and Las Tuerces, at the Northeast of the Palencia province (Castille and Leon Autonomous Community, Northern Spain). The small quadrangle represents the area of Fig. 2

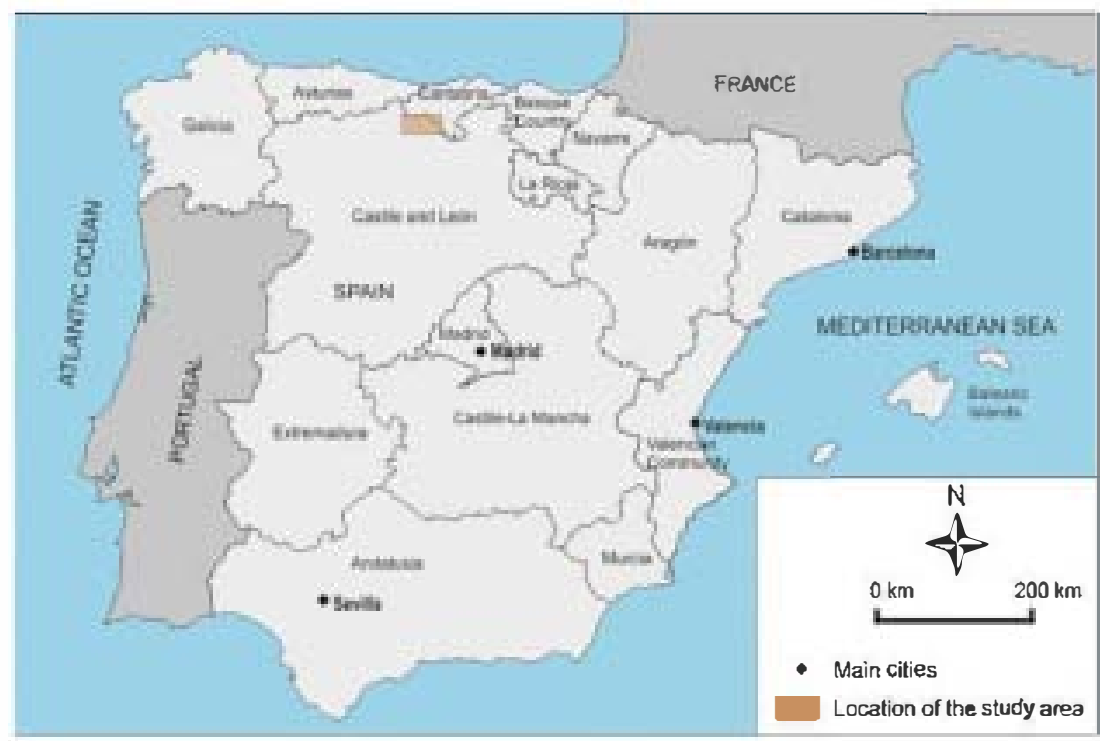

A preliminary analysis of the areas under study was carried -ut by the GAMA envirenmental consultants (see the Acknowledgements section for dewils) in 2008 (but was not published), allowed a series of essential factors to be identified when designing a management system to encourage the development of cetourism. In fact, both Covalagua and Las Tuerces already $\bullet$ ffer interesting development $\bullet$ pp $\bullet$ rturities for this type of tourism:

B॰th landscapes are visited by a significant number of people, because of their eomorphological values, with Los Franceses cave (Fig. 4 (4.2)) currently receiving around 15,000 visitors/year.
They already have some existing tourist infrastructure, including viewpoints, paths, parking areas, information panels and signpested trails.

Both areas have zoed road access.

Some recreational facilities are already located there, being specially popular for speleologists and climbers because of the many karstic caves and rock cliffs, although the number of visitors is still relatively small (n॰n-mass tourism, specific and complementary).

The area has $\bullet$ ther elements of cultural interest, which complement the eco-tourism. These include a pilgrimase at Lus Tuerces site and some of the best Romanesque churches in Spain around both places.
Fig. 2 igital elevations mødel - f the Covalagua and Las Tuerces area, showing the top-graphic framework of the study area. Heights in meters abøve sea level

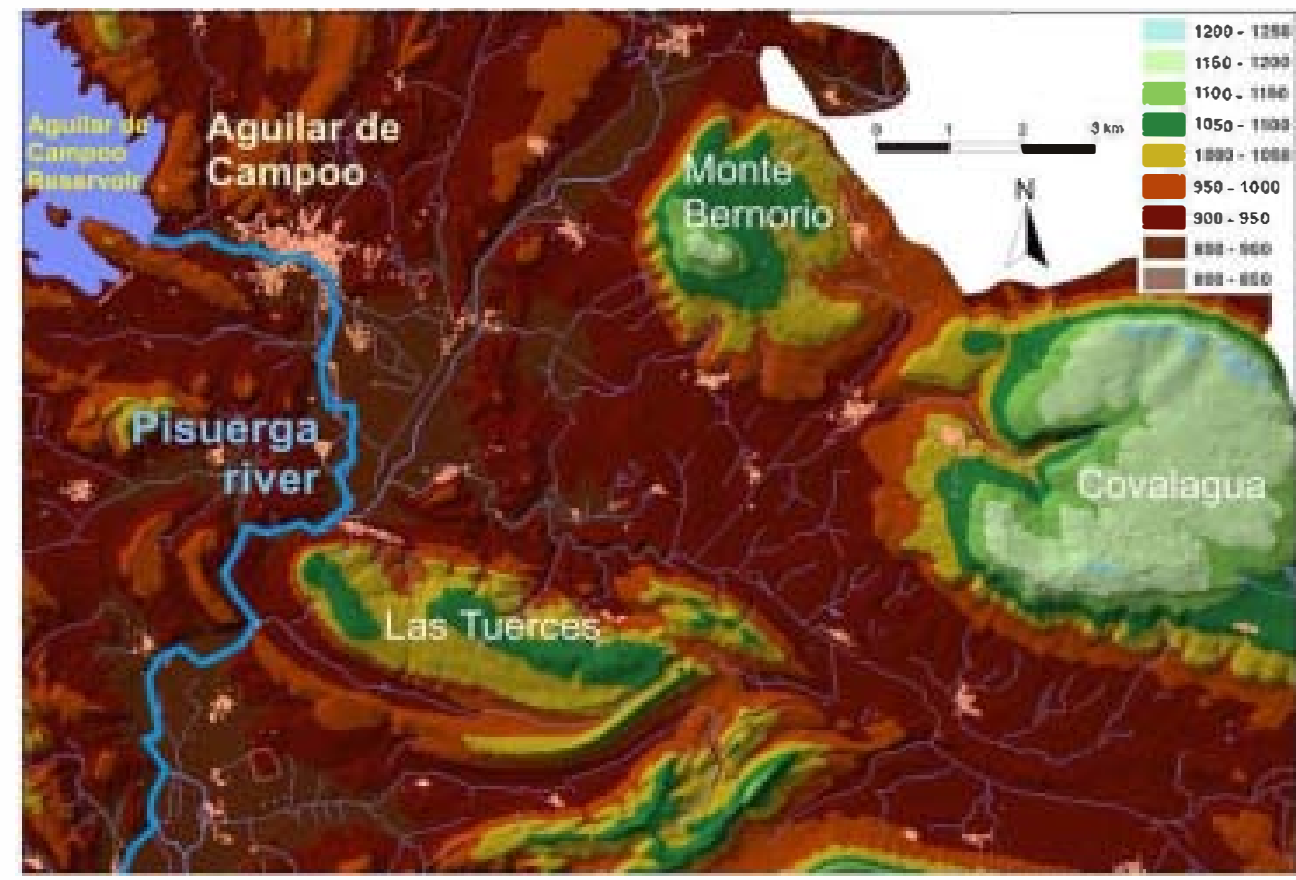



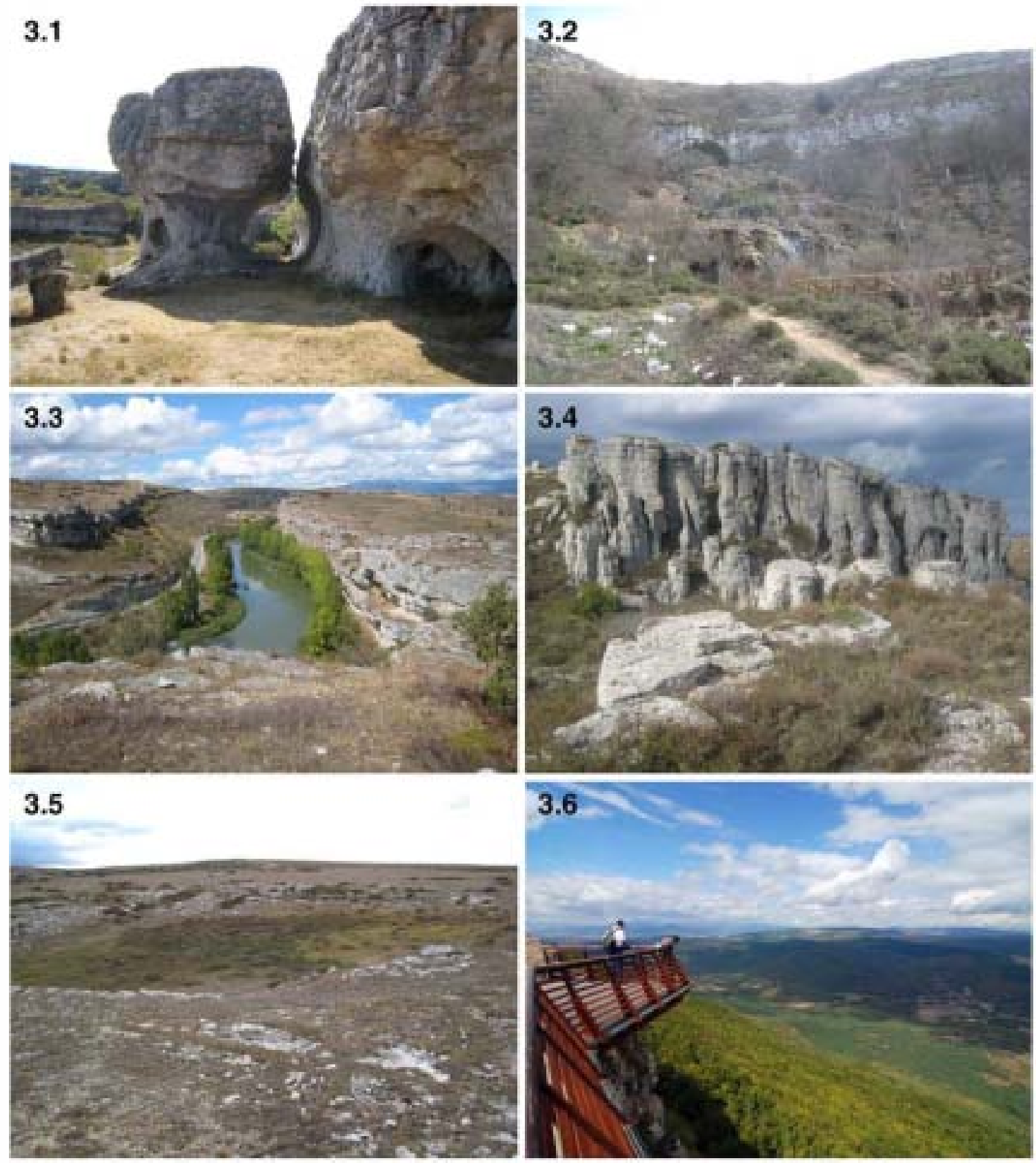

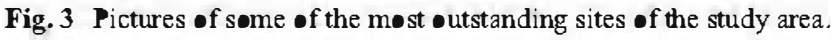
3.1, Las Tuerces labyrinthic karst; note, between the two rock masses, a forner phreatic tube-like cave, with roughly circular cross-section, ev॰lved to a superficial corridor. 3.2, Spring and tufa depøsit of Covalagua; although it can be barely seen, the centre of the image is a large tufa barrier. 3.3, La Hor adada fluvi -karstic cany on, a relevant example of a limestone canyon cut into a cuesta (limestone platf orm with a general dip slope to the East to the right of the image); the canyon scarps hold many learstic cavities and are subject to significant rock falls. 3.4, La Horadada castle-like learst, alse called ruinif orm karst, because of similarity with a mined building. 3.5, A sinkhøle

Some interesting interpretative initiatives have been ins alled, with various seological itineraries, explanatory panels and a geological field guide (Basconcilles et al. 2006).

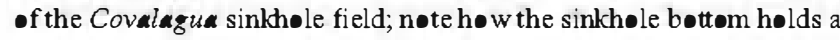
grassland community; this community fits precisely with soils which conf orn exactly with the clayey deposits--residual of the limestone weathering-that fill the bottom of the sinkhole. 3.6, the Valcabado viewp•int, løcated at the Northern edge of the Lora de Valdivia (Covalagua); oustandingly, this edge is a sharp boundary between the Eurosiberian and Mediterranean phytogeographic regions of the Iberian peninsula. The trees below the viewpoint forn a beech forest, belonging to the forner region. See Fig. 4 for the location of this pictures

As a result $\bullet$ the flow of visit res to both areas since the mid-1990s, a limited tourist infiastructure has been the development in the nearby villages. Newadays, the ten nearest villages $\bullet$ ffer a total of 16 registered accommodation 
Fig. 4 Identification and location of some of the geosites referred within the text at $L$ as Tuerces (a) and Covalagua (b) natural areas. The boundary of the studied area, shown by the line, was delineated by the regional government. a $1, L$ as Tuerces larst corridor (see picture 3.1 in Fig. 3); 2,

Recuevas valley, $3, \mathrm{~L}$.

Horadada fluvio-karstic canyon (see picture 3.3 in Fig. 3); 4, 2a Horaduda castle-like karst (see picture 3.4 in Fig. 3). b 1, gøed examples of collapse sinkhøles; 2, spring and tufa dep $\bullet$ sits of Covalagua (see picture 3.2 in Fig. 3); 3, entrance to the Los

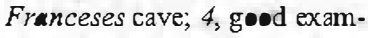
ples of soution sinkh les (see picture 3.5 in Fig. 3); 5, Valcabado viewp int, 6, Ebrø valley. Picture 3.6 in Fig. 3 shows both the Valcabado viewpoint and the Ebrøvalley, with the beech forest in in valley slopes at this location. Specifically, this $\bullet$ verlay of the orthophote with the Digital Elevation Model allows the visualization of the sharp boundary between the Euresiberian and Mediterranean phytogeographic regions of the Iberian peninsula, being this large ecosystem limit the upper bo undary of the forest (dark green colour around o)
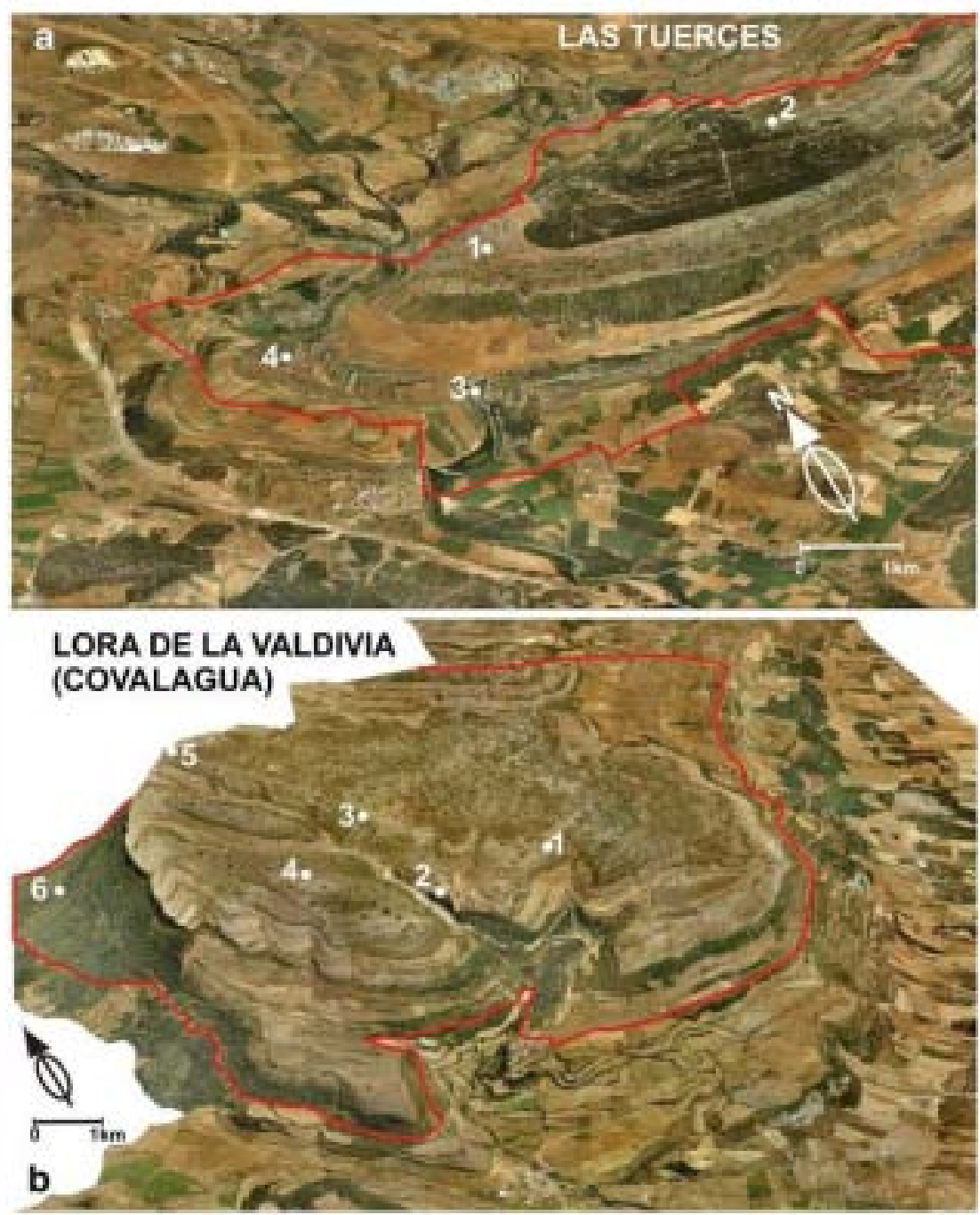

venues with 115 beds and four restaurants seating 203 diners. Althou this is currently the mest significant ecenomic activity in the area, and the enly sector which is expanding, the fact is that it is scattered and the occupation is irregular, being very seas $\bullet$ nal. Therefore $\bullet$ ther sect $\bullet$ the local economy are not significantly affected by these activities at present.

\section{Methodelogy}

The geeherimge, zeocenservation and geoteurism studies described below were part of a natural resurce planning study aimed to declare a protected area including the tove sites (Covalagua and Las Tuerces, Northern Spain). But rather than merely $\bullet$ ne part of the whole, the geomerph logic traits and significant geological heritage were the main focus of the generitage interest in the PORN. The whole process was focused by the geølegical and geomerphological information, as reflected in the land zoning and assessment, primarily based $\bullet$ the geomerphelogy (Santes and Herrera 2010). Even the catalogue of habitats and landscapes and the land use structure was based on the geomerphology. A study - $f$ the geological heritage of the area was cardinal because identifying the geosites and geomerphosites of significant scientific, cultural, educational and geoteurism value was a key factor in the final design of the land management system.

The first methodological phase was a geølegical and seomorpholegical inventery. The primal $\bullet$ bjective was to summarise the gemerph cartography for planning purpeses, in acordance with the planning $\bullet$ bjectives (with geoconservation and geøtourism being essential within them), over a detailed conventional catal $\bullet$ of eological elements. The assesment and diagn $\bullet$ tic phases were developed then, in accordance with similar -bjectives. As a result, legal planning and management regulations, including geecenservation and public use measures were written.

Certain recurrent issues, $\bullet$ ften detected in Natural Res Management Plans and other similar documents, were avoided, 
e.s. (a) lar a amount of useless information for planning and manazement purpeses included in the final decument and (b) the absence of relationship between the information included in the inventery and that included in the evaluation, diagnesis and regulation phases, which dees not shows any causal relationship (see Figs. 5 and 6).

Inventery Phase

The first step was to identify the geelegical characteristics and features of the area, to be able to analyze their value and potential in terms of cetourism and so plan their manazement apprepriately. The inventery was based on the classification, mapping and description of hemegeneous land areas. At this stage the landforms (including lithelegy, topozraphy and zeomerph legical processes) were considered to provide the best synthesis of the land. This meant that rather than using a geomerpholegical classification and mapping organised by zenetic criteria (i.e. attempting to explain the erigin of the different landforms), the classification was based on ecological and landscape criteria: i.e. pricritising the shape of the landforms, independently of how they were formed, and the characteristics of these which dictate hew they should be 'managed'. In this case, the land classification was intended to guarantee a homegeneeus respense the landforms in terms of planning, public use and manazement as a protected natural area.

T- dhis, a three-level classification was designed. The basic mapping element was the gemerphelegical unit (35 units), represented by land pelyzons cevering the total 'planning area' (Table 1; Fis. 7). The gemerphelegical groups include a certain number of related gemerph cal unit to provide a landscape context. Three geomerph løgical groups were identified: I, uplands of Las Løras; II, slepes and valleys; and III, alluvial plains (Table 2; Fi. 8). Finally, the gemorpholegical features of interest (16 features) characterise the units where they are found, providing an additional level of infermation (Table 3; Fig. 9). These features are not unit-specific, and any element (e.s. a sinkhele) may be found in different units. Some micr landforms were als defined, being a fourth (nen-mappable) level, which refer to the mest characteristic features - karstic micromerphogies i.e. the types ef kurren (Table 4).

The criterion for identifying and defining the geomerphological units and features of interest was based on a classification of ex karstic landforms, altheugh the representation methed varied. In a conventional geomerphlozical appreach, the landforms are represented by symbels and colours, of limited use for planning (e.s. many land areas are left 'blank'). The approach used in Covalagua and Lus Tuerces represents groups and units by pelyzons and features of interest by pelyzons and peints. This means that the map is directly intended for planning and manazement purpeses and it is als compatible with the spatial dat structure of a vector based Geographical Information System.

In accordance with the main bjective of these maps and the inherent difficulties of any land form classification (since some landforms tend to evelve gradually int others), the limits and criteria for unit differentiation were set precisely fiom a planning viewpeint for public use and essentially getourism, being each unit homegeneous in terms of its behaviour and respense. The distinction, for example, between gemerphelegical units 2 and 3 uses 'walkability or nen-walkability efkarst corriders' as a criterion. This example is very interesting in methedelegical terms, because a strictly

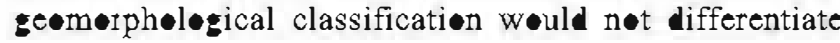

Fig. 5 Organising of the ge $\log$ ical and geomorph $\bullet$ logical information aimed at the planning of natural resources in protected areas. Mødified fr $\bullet m$ Warrington (2004)

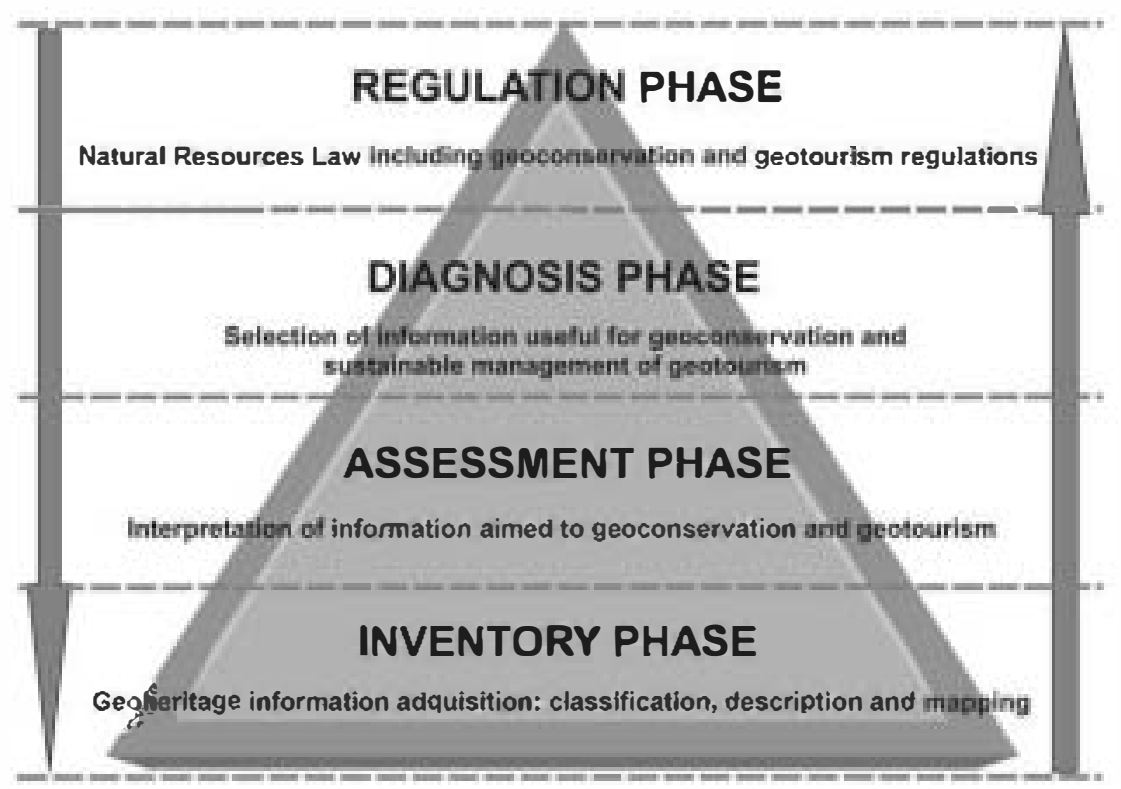


Fig. 6 Integration of the

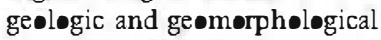
studies in the Plan of Covalagua and Las Tuerces

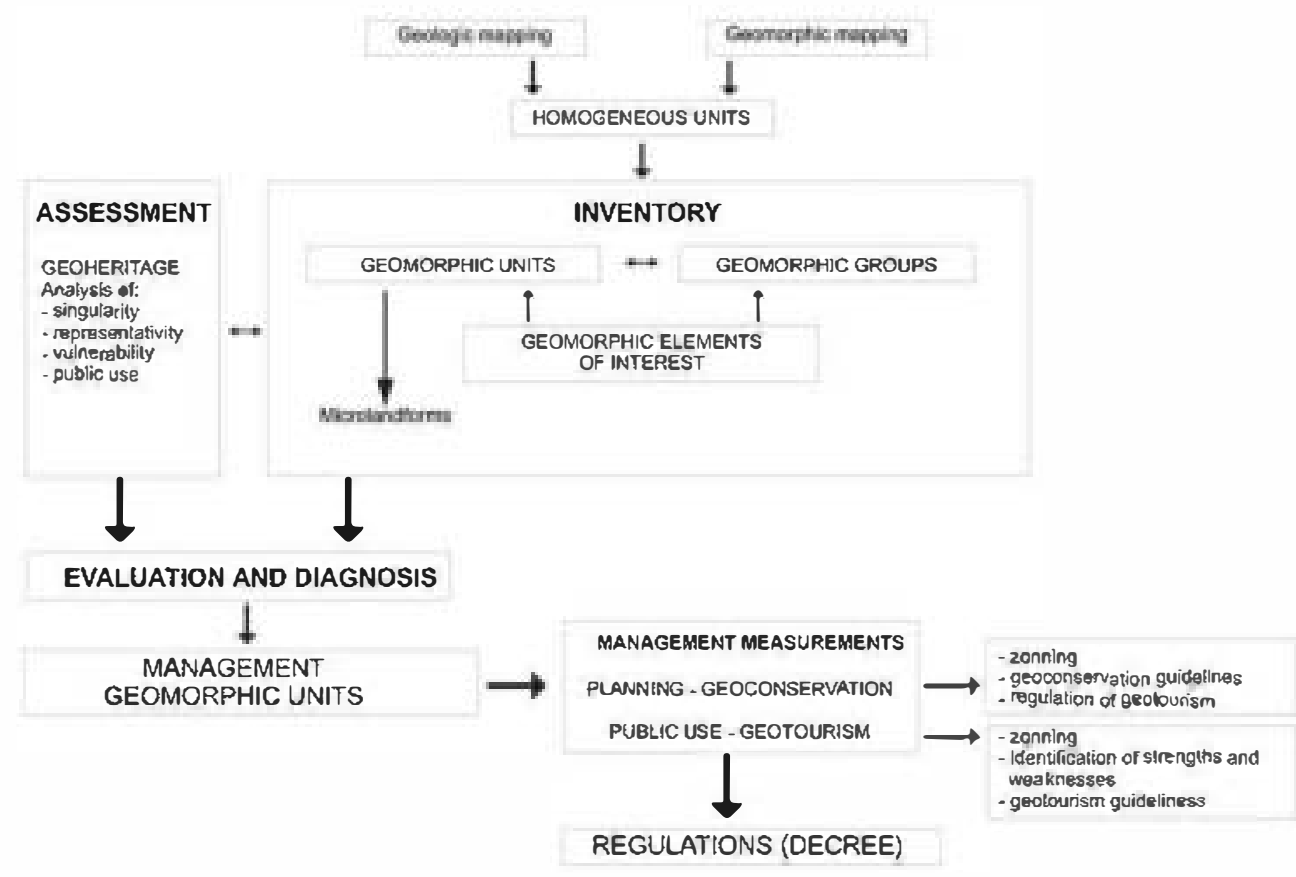

between these two uniw. The inventery approach is therefore 'dicuted' by the main geals of planning, conservation and geøturism, which was a requisite and $\bullet$ bjective $\bullet$ this Natural Resurces Management Plan (Fig. 10).

Finally, a brief description of the geological groups, units and features was included. It was considered necessary to highlight these remarkable characteristics including geeconservation useful for planning; for example, weathering of the limestone at this site preduces collapse sinks when exposed near the surface.

\section{Assessment Phase}

The gcomorphological groups, units and features were later interpreted and assessed in the following terms: (1) their potential within the context of a protected area (special characteristics, scientific, educational, visual, recreational or tourism interest) and (2) their limitations (risks inherent in the active geomorphølogical prøcesses, e. subsidence or rock falls), or e-ecological precess vulnerability. Their level $\bullet$ preservation was als assessed, as this fact significantly affected their planning and manazement.

The study included a specific analysis on the singularity and representativeness (Welfert 1995; Carcavilla et al. 2007) of the most characteristic landscapes of both areas; these are the labyrinth karst (b॰gaz) of Las Tuerces and the sinkhole field of Covalagua. This analysis was based - $n$ a compilation of ther examples of karstic landscapes in Spain (Fig. 11), drawn up from a bibliegraphic analysis and through direct consultation with specialists in karstic geomorphology in Spain. This consultation was carried out through an ad hoc survey that asked to identify bøgaces and sinkhøle fields through Spain and Castilla y Len. For that, there were included descriptions of Covalagua and Las Tuerces sites for comparative porpuses. Seventeen specialists were consulted, and everyone responded the survey. The specialist selection was based on their recent research on Spanish karstic sites.

The analysis of the information showed that there were few samples of laberinth karst in Spain, making Las Tuerces a significant feature in the national listing. Lus Tuerces is als a very seod sample of ene of the mest typical karst landscapes. This makes it both singular and representative.

Sinkhole fields are more commenly found than labyrinth katsts, both in Spain and worldwide. Covalugua has a total 387 sinkholes over an area of $10.1 \mathrm{~km}^{2}$, which means a density of 38.3 sinkholes $/ \mathrm{km}^{2}$, which in certain sectors is even higher (53.1 sinkhøles $/ \mathbf{m}^{2}$ ). This sinkhole concentration, one of the highest in Spain, makes this an area of considerable natural value.

\section{Diagnestic Phase}

According the previous interpretation and assessment phases, the relevant information was selected for natural resource and public use planning, including geot urism. In ther words, in this phase the generic and specific seconservation and geotourism management measures were developed.

The first conclusion of the diagnesis was that both Covalagua and Las Tuerces should be declared protected areas, because they represent tw $\bullet$ of the best examples of karstic landforms at the North-Central resion of Spain. In pøint of fact, new envirenmental legislation in Spain adv cates the protection of 'Karstic systerns in carbonates and 


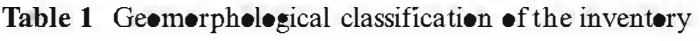

\begin{tabular}{|c|c|c|c|c|}
\hline \multirow[t]{2}{*}{ Códe } & \multirow[t]{2}{*}{ Name } & \multicolumn{2}{|l|}{ 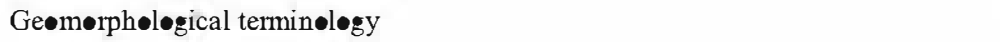 } & \multirow[t]{2}{*}{ Løcal name } \\
\hline & & Internatiønal & Spanish & \\
\hline 1 & $\begin{array}{l}\text { Røcky pavements with } \\
\text { karren surfaces }\end{array}$ & $\begin{array}{l}\text { Limestone, pavement, karrenfeld } \\
\text { and kluftkarren }\end{array}$ & Pavimentos Lapiaz estructural & \\
\hline 2 & $\begin{array}{l}\text { Narrøw cørridør karst } \\
(\text { n॰n-walkable) }\end{array}$ & $\begin{array}{l}\text { Kluftkarren, giant grikelands, } \\
\text { b•gaz, corridors karst, labyrinth }\end{array}$ & $\begin{array}{l}\text { Callejønes, cørredøres and zanjønes } \\
\text { (Iberøam.) megalapiaces macrølapiaces }\end{array}$ & \\
\hline 3 & Walkable corrider karst & karst and bøx valleys & lapiaces gigantes ciudades encantadas & \\
\hline 4 & Walkable sløpe corrider karst & & & \\
\hline 5 & $\begin{array}{l}\text { Oval corridor karst and } \\
\text { closed depressions }\end{array}$ & & & \\
\hline 6 & $\begin{array}{l}\text { Castle-like karst with } \\
\text { corriders }\end{array}$ & Ruiniform karst and castle-like karst & Karst ruiniforme & \\
\hline 7 & $\begin{array}{l}\text { Flat surfaces with karst } \\
\text { towers }\end{array}$ & Karst towers & & Torres \\
\hline 8 & $\begin{array}{l}\text { Aligned cavern (cøllapse) } \\
\text { sinkhøle fields with } \\
\text { angular karren }\end{array}$ & Aligned sinkhøle field & Campøs de delinas alineadas & Torcas \\
\hline 9 & $\begin{array}{l}\text { Aligned finnel (sølutiøn) } \\
\text { sinkhøle field }\end{array}$ & & & 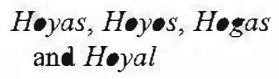 \\
\hline 10 & $\begin{array}{l}\text { Sløpe valleys and small } \\
\text { alluvial plains } \bullet \text { uplands }\end{array}$ & & & \\
\hline 11 & Small razørbacks $\bullet$ n uplands & Razørback & Crestas & \\
\hline 12 & $\begin{array}{l}\text { Karren and søils } \bullet \text { n cuestas } \\
\text { backs }\end{array}$ & Hølhkarren Kavernøsekarren & $\begin{array}{l}\text { Campos de lapiaz tubular and dorses } \\
\text { de cuesta }\end{array}$ & Lanchar Lastras \\
\hline 13 & 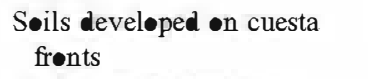 & Cuesta frønts & Frentes de cuesta & \\
\hline 14 & $\begin{array}{l}\text { Røcky scarps } \bullet \text { cuesta } \\
\text { frønts }\end{array}$ & & & \\
\hline 15 & Karstic platea & Platea & Depresiønes cerradas, c $\bullet$ paredes verticales & Recuevas \\
\hline 16 & 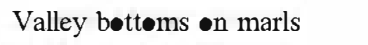 & Subsequent valleys & Valles •rtøclinales (subsecuentes) & \\
\hline 17 & $\begin{array}{l}\text { Small kn॰bs } \bullet \text { limest॰ne } \\
\text { uplands }\end{array}$ & Hill and kn॰b & Pequeñas mesas & \\
\hline 18 & $\begin{array}{l}\text { Tilled fields } \bullet \text { n marls } \bullet \text { n } \\
\text { uplands }\end{array}$ & & & \\
\hline $\begin{array}{l}19 \\
20\end{array}$ & $\begin{array}{l}\text { Dry valleys } \\
\text { Tilled dry valleys }\end{array}$ & Dry valley & Valle sec• & $\begin{array}{l}\text { Valseca and Calleje } \\
\text { Valseca }\end{array}$ \\
\hline 21 & Small valleys & & Valles cataclinales (cønsecuentes) & Valleje and Vallejuele \\
\hline 22 & Hillsløpes $\bullet$ n marls & Hillsløpes $\bullet$ marls & Laderas søbre margas & Cuestas \\
\hline 23 & Limestøne cliffs & Cliff and alcøves & Cantiles and cortades & Rompizenes \\
\hline 24 & Høgbacks and razørbacks & H•gback and razørbacks & Crestas and crestones & \\
\hline 25 & Fall headwalls & Headwall (fall) & Cicatrices de arranque de desprendimientos & \\
\hline 26 & Scree sløpes & Talus sløpe and scree sløpe & Canchales & \\
\hline 27 & Debris $\bullet$ sløpes & Cølluvium & Coluvión & Cuestas \\
\hline 28 & Fløedplains & Flı•dplain & Llanura de inundación & La Vega \\
\hline 29 & Fluvial terraces & Terraces & & \\
\hline 30 & $\begin{array}{l}\text { Tilled karren and søil } \\
\text { surfaces } \bullet \text { uplands }\end{array}$ & & & \\
\hline 31 & Terraced sløpes $\bullet$ n marls & Terraced sløpes & Laderas aterrazadas & \\
\hline 32 & $\begin{array}{l}\text { Small quarries } \bullet \text { n } \\
\text { colluvium }\end{array}$ & Quarry & & \\
\hline 33 & $\begin{array}{l}\text { Sp॰il heaps } \bullet \bullet \bullet d \text { lignite } \\
\text { mines }\end{array}$ & Sp•il heaps and waste dumps & & \\
\hline 34 & Limestøne quarries & Quarry & & \\
\hline 35 & Silica sand quarries & & & \\
\hline
\end{tabular}

Geømørphøløgical units 


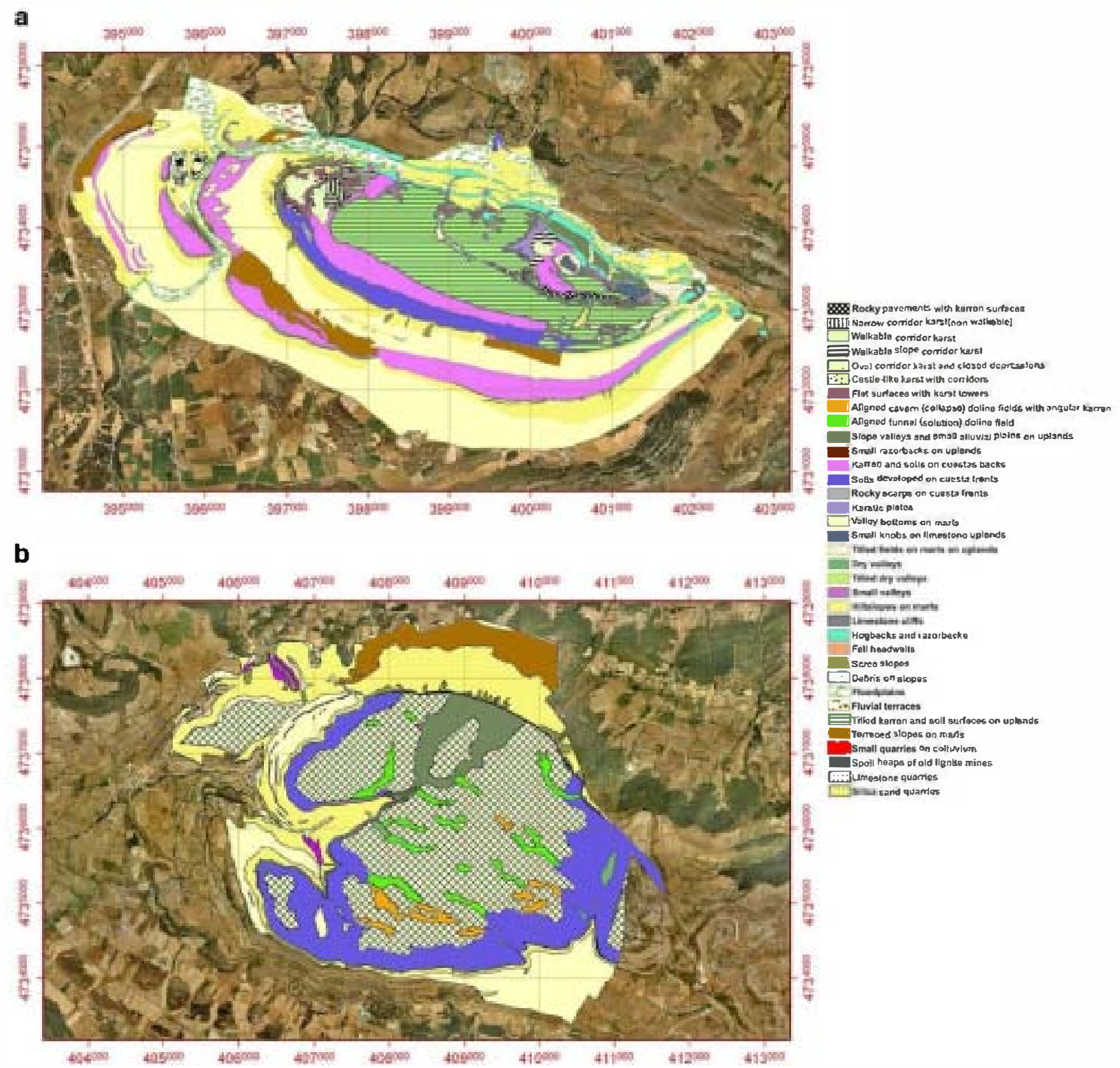

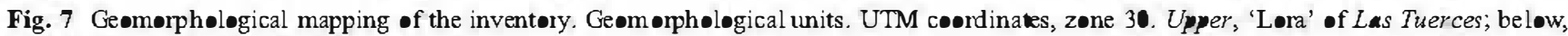
'Lora' of Valdivia (Covalagua)

evaporites in the Iberian Peninsula and Balearic Islands' as -ne of the 20 Spanish geological settings of higest international relevance (Carcavilla et al. 2009) and Covalagua and Las Tuerces represent excellent examples of of such systerns.

In both cases, their valuable geomorphological heritage is the result of a spatial converence of utrunding karstic features. At Covalagua: sinkhole field; the Covalagua spring and tufa deposits; the Los Franceses cave; a rich and varied karren typ-logy; and the Valcabado viewpoint. At Las Tuerces: its labyrinth karst; the fluvio-karstic sorge of $L \boldsymbol{a}$ Horadada, a relevant example of a limestone canyon with significant rock falls on its valley slopes and many karstic cavities on the scarp face; a castle-like relief within the gor of $L$ Horadada; the Recueves valley; and als with a wide range of karren. It is, in fact, the overall grouping of these individual features and their inter-relationships which makes these tov armas natural sites of especial impernance.

The diagnesis alse indicated that the combination of these two natural areas offered enormous pessibilities for promotion and education, and hence for seourism (Hose 2000 and 2012). Currently, it receives thousands of visitors (potentially as true geotouris in the future) per year interested in some of these facets. Although quality geological infermation and interpretative material intended for the 
Table 2 Geomøph logical classification of the inventory

\begin{tabular}{|c|c|c|c|c|c|}
\hline \multirow{5}{*}{$\begin{array}{l}\text { Table } 2 \text { Geomorpholøgical } \\
\text { classification of the inventory }\end{array}$} & \multirow[t]{2}{*}{ Cøde } & \multirow[t]{2}{*}{ Name } & \multicolumn{2}{|c|}{ 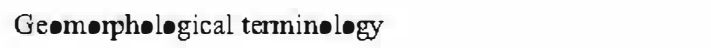 } & \multirow[t]{2}{*}{ Løcal names } \\
\hline & & & International & Spanish & \\
\hline & I & $\begin{array}{l}\text { Uplands (Las } \\
\text { Loras) }\end{array}$ & $\begin{array}{l}\text { Mesa and synclinal } \\
\text { uplands }\end{array}$ & Sinclinal colgadø, mesa and muela & Párames and Loras \\
\hline & II & $\begin{array}{l}\text { Slopes and } \\
\text { valleys }\end{array}$ & $\begin{array}{l}\text { Cuestas, hogbacks, } \\
\text { razorbacks, } \\
\text { ridges and valleys }\end{array}$ & $\begin{array}{l}\text { Valles y depresiones } \bullet \text { rtoclinales } \\
\text { (øbsecuentes), cuestas y valles } \\
\text { and crestas y valles }\end{array}$ & \\
\hline & III & Alluvial plains & Aluvial plain & Llanura fluvial & Vegas \\
\hline
\end{tabular}

Geomørphølogical groups

Eeneral public already exists, it needs to be completed (increasing the contents on geomerphology) and impreved (the tex should be more simple and appealing for the visiters). The current infiastructure including paths, walkways, viewpoints, a touristic cave and information panels provides an excellent foundation for setting up other interprentive facilities. Gremorphological features are not sufficiently developed and should be further expleited, supperted by karstic landscapes. In additien, it sheuld be combined with other biological and archaeological features, whenever it was possible. The areas of Covalagua and Lus Tuerces could als be used to develep a whole suite of interprentive material for Las Loras, a structural geologic landscape system of undeniable heritage value fiom many peints of view.

Tourism linked to the geolegical and geomerphelegical attractions, that is getourism (Hose 2000, 2011, 2012), could be considered as the local economic activity with the highest petential for rowth in this area and its immediate hinterland. There are ne data recerds of geot urists for the area, due the lack of geturism visitor surveys, although aneclemal evidence suggests that there -nly seems to be significant visiter activity in the summer time as has been indicated in karstic regiens in suth-east Spain (Hese 2007). The majer exception is for climbing and related activities in the karstic Recueves valley that eccur througheut the year. Les Franceses cave, on the ther hand, receives 15,000 visits/year (knewn because the visiters have to buy tickets), which are channelled int other points of interest in the area (Covalagua spring, Valcabado viewpoint). The considerable local tourist potential of Covalagua and Lus Tuerces will be reinforced as they are to be declared natural protected areas, but the structural weaknesses are evident, as this tourist activity is clesely linked to specific resurces, with considerable pulling power but which only generate shert visits. The shert visits are larely made by emigrants whe come back to spend their summer helidays in the lecal villages.
Fig. 8 Geomorphological mapping of the inventory. Geomørphølogical groups. UTM coordinates, zone 3

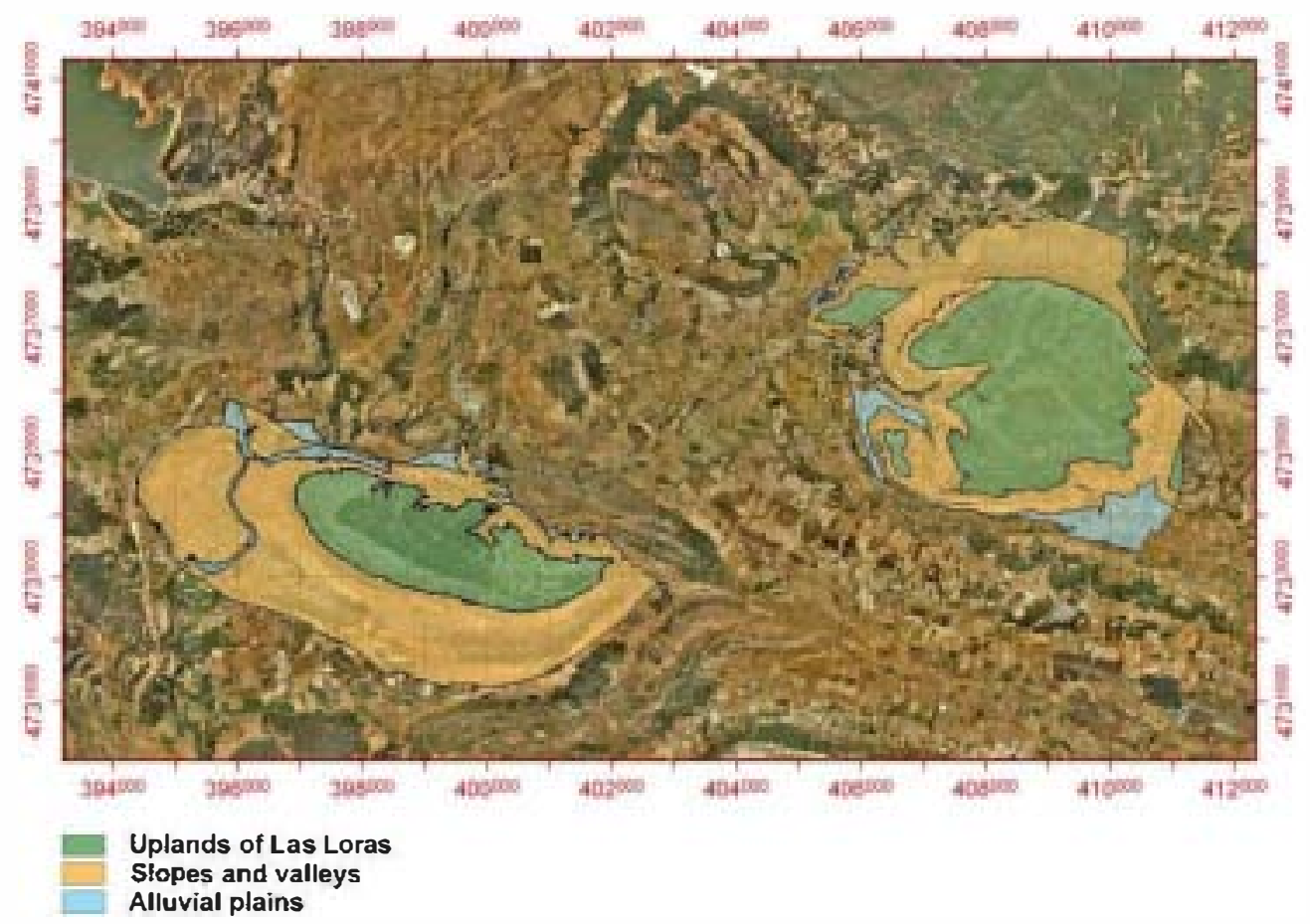




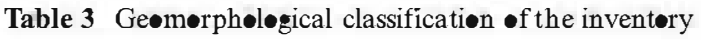

\begin{tabular}{|c|c|c|}
\hline Code & 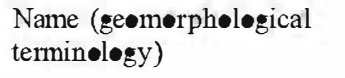 & Løcal name \\
\hline A & $\begin{array}{l}\text { Sinkhøles (finnel type and } \\
\text { sølution) }\end{array}$ & 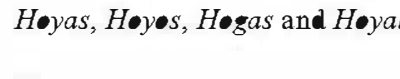 \\
\hline B & $\begin{array}{l}\text { Sinkhøles (cavern type and } \\
\text { collapse) }\end{array}$ & Torcas \\
\hline $\mathrm{C}$ & Uvalas & \\
\hline $\mathbf{D}$ & Small karst p•wers & Torres \\
\hline $\mathrm{E}$ & Sinks & \\
\hline $\mathrm{F}$ & Caves & \\
\hline G & Natural bridges and arches & \\
\hline $\mathrm{H}$ & Alcøves & \\
\hline I & Corrider karst & \\
\hline $\mathrm{J}$ & Tufa & Toba \\
\hline $\mathrm{K}$ & Springs & Manantiales \\
\hline $\mathrm{L}$ & Røckfalls & \\
\hline M & Gullied sløpes & \\
\hline $\mathrm{N}$ & Active channels & \\
\hline - & Ephemeral channels & \\
\hline $\mathbf{P}$ & Abandoned channels & \\
\hline
\end{tabular}

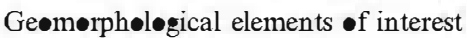

\section{Regulation Phase}

Once the phases above were completed, the planning and management measures were defined, to guarantee the appropriate conservation $\bullet$ the natural values of the area, and als to ensure compatibility with the measures to maximise its potential for public use and local development, including geotourism.

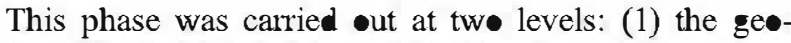
logical team established measures referring to the geological and geomorphological elements, and the specialists responsible for other theme-based studies (such as biølogical or cultural) did the same. In other words, the specialist teams defined their own measures, which were then compare and discussed by the team as a whole in various jøint meetings; (2) in these meetings, other management measures were adopted in relation to the natural and cultural resources as a whøle, based on the conclusions of the søci-ecønomic study. These jøint decisions referred specifically to: (a) land zoning, (b) regulating uses and activities and (c) defining conservation measures. In this phase, the local authority responsible for the future management of these natural areas played an important role, thus ensuring that the propøsal was alsø appropriate to its aims and action capacity.

Søme of the conclusions reached which are most relevant to geconservation and geotourism are shown below. It shøuld be noted that $\bullet$ ne the main advances of this prøject is that these conclusions are reflected in the officially approved regulation and are therefore mandatory. Hence, they should be actioned in the future.

\section{Land Planning and Geoconservation Measures}

The information collected and generated led the preparation of land planning and geoconservation guidelines. The -fficial guidelines for the environmental protection of both natural areas describe: (1) the characteristics considere of value of each area and (2) the specific •bjectives to preserve the integrity of the formations and their active geological and geomorphøløgical processes, and to bøost their heritage, interpretative, educational and scientific values - all essential undeprinnings of geotourism provision.

As an integrated conservation measure, the declaration of a single Protected Landscape Area (PLA) was proposed, comprising both the Covalagua and Las Tuerces natural areas, which actually took effect in 2011 . The protected area totals 4,340 ha, divided int tw॰ sub-areas, with a protected peripheral buffer zone. The main aim of this PLA is to 'preserve and protect its natural values, habitats, flora, fauna, landforms and landscapes, to preserve its geodiversity and biodiversity and maintain and/or optimise the dynamic and structure of its ecosystems' (Junta de Castilla y León and GAMA 2010).

The presence of singular gelogical features and their inherent fragility was essential als $\bullet$ when defining a land zoning, linked with different regulations for the protection and public use for each zone.

Other regulations were developed to address the protection of the dynamics of the karstic processes that have shaped this landscape and are still currently active. To guarantee the maintenance of the active processes invelved, ensuring that water infiltration int the karstic sinkhøles is not interrupted, to maintain the natural resurgence rhythms of the springs (which in tum affects the development of the tufa deposits) and av॰iding any alteration of the hydrølogical cycle.

To warrant the appropriate conservation of the natural values of these areas, the regulatory measures stipulate als that projects propose for this area that are subject to Envirønmental Impact Assessment must øbtain a favøurable report from the relevant Natural Area Authørity.

T॰ sum up, the outcome of the phases described ab॰ve was to establish guidelines for the conservation of the geological and geomorphølogical processes and assets, including proposals to: (1) prevent any mining, construction and earth moving activities which might alter the volume, profile or -ther natural or landscape characteristics; (2) protect the active gelegical processes within the natural areas, especially the karstic prøcesses, where these $\bullet c c u r$ on karren surfaces •r $\bullet$ -ther features, avoiding any activity which might interrupt $\bullet$ disturb these processes; (3) bøost the educational potential and 


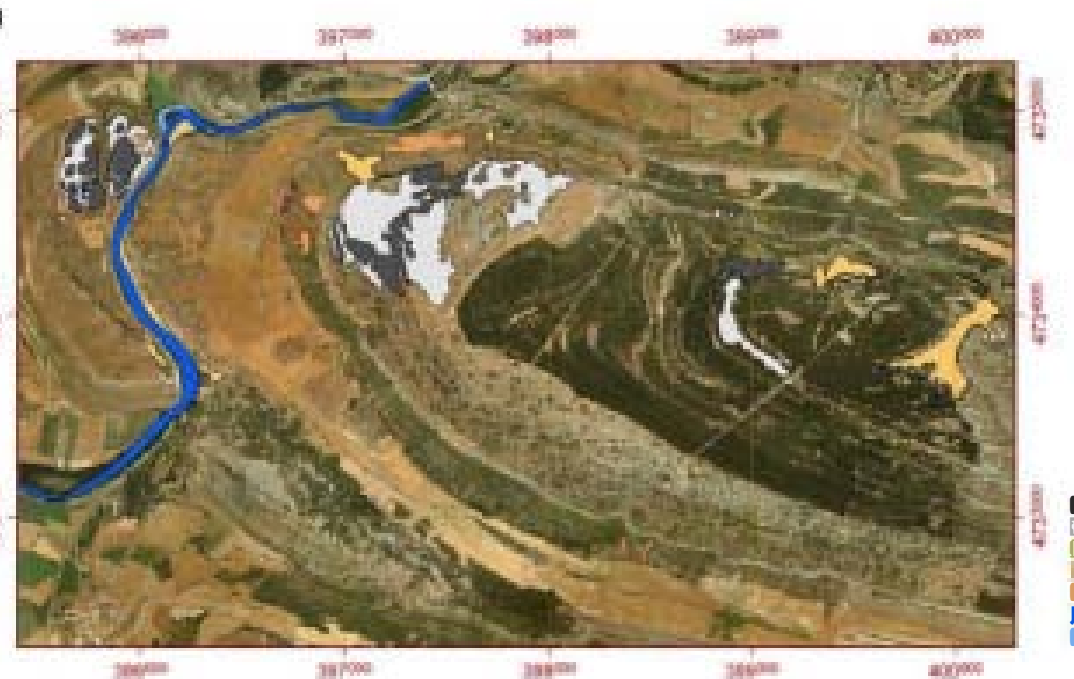

Small karst towers Corrldor karst Tufa

Rockfalls

Gullied slopes

Active channels

Abandoned channels

b

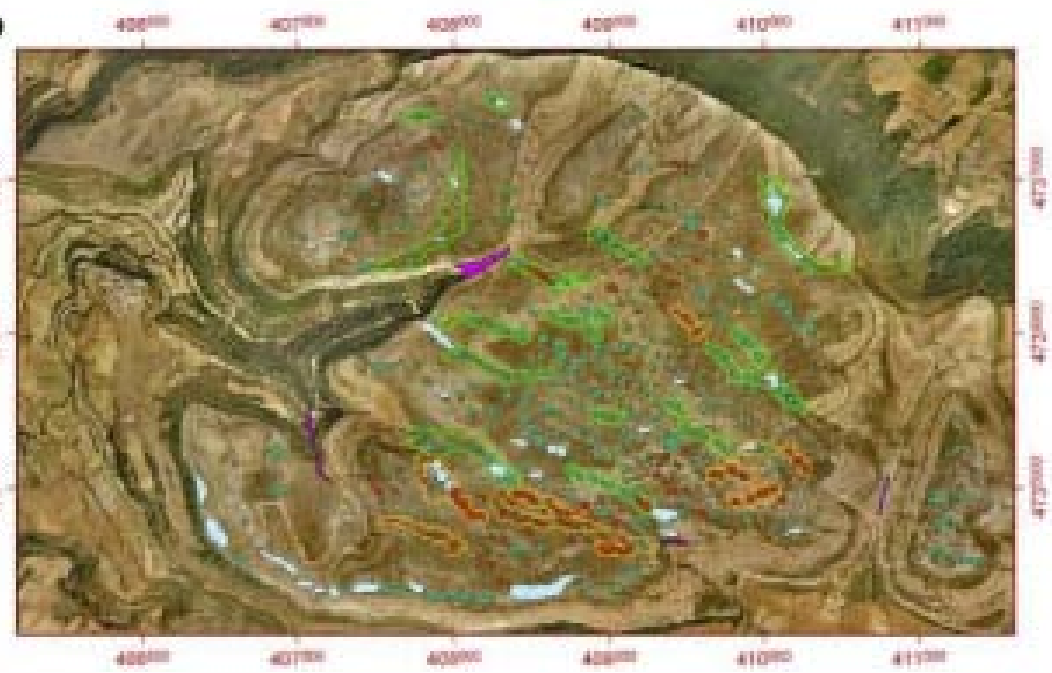

Sinkholes (fitnnel type, solution)

Sinkholes (cavem type, collapse) Uvalas

Tufa

Gullied slopes

Aligned cavern (collapse) doline fields with angular karren

Aligned funnes (solution) doline fieló

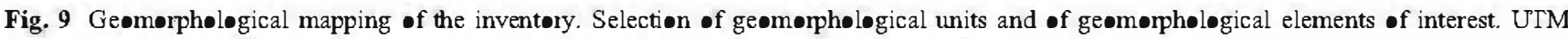
coordinates, zone 30. Upper, 'Lora' of Las Tuerces; below. 'Lora' of Valdivia (Covalagua)

public use f the geelegical and gemerpholegical resurces of the natural areas, installing signpesting; (4) stablish specific zuidelines for restoring areas affected by public works or private facilities; (5) promete systematic study and inventory - f existing caves within the natural areas and ensuring an use compatible with their conservation; (6) encurage a wider understanding and scientific prometion of the seomerpholegical features and precesses, and the development of the petential interprentional, educational and public use compatible with conservation as already utlined; and (7) devise an appropriate model to develop the educational and interprentive potential, suaranteeing the conservation of landforns and precesses.
Table 4 Geomørphølogical classification of the inventory

Karstic surficial microlandfonns. Karrentypes

\begin{tabular}{|c|c|c|}
\hline Karren terminølogy in Spanish & $\begin{array}{l}\text { Internatiønal karren } \\
\text { terminøløgy }\end{array}$ & $\begin{array}{l}\text { Geomørph } \bullet \text { gical unit which } \\
\text { characterise }\end{array}$ \\
\hline Micrødølinas and tinajitas & $\begin{array}{l}\text { Kamenitzas, sølution basins, } \\
\text { solution pits and pans }\end{array}$ & $2,3,4$ and 5 \\
\hline Lapiaz en estrias & Rillentarren & \\
\hline Lapiaz redondead• & Rundkarren & \\
\hline Lapiaz en surces & Rinnentearren & 8 \\
\hline 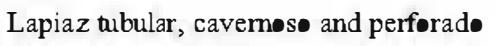 & Hølhkarren Kavemøselearren & 1 and 1 \\
\hline Lapiaz structural & Kuftearren & $\begin{array}{l}\text { 1; alsø } 2 \text { a } 5 \text {, but at a landscape } \\
\text { scale }\end{array}$ \\
\hline
\end{tabular}




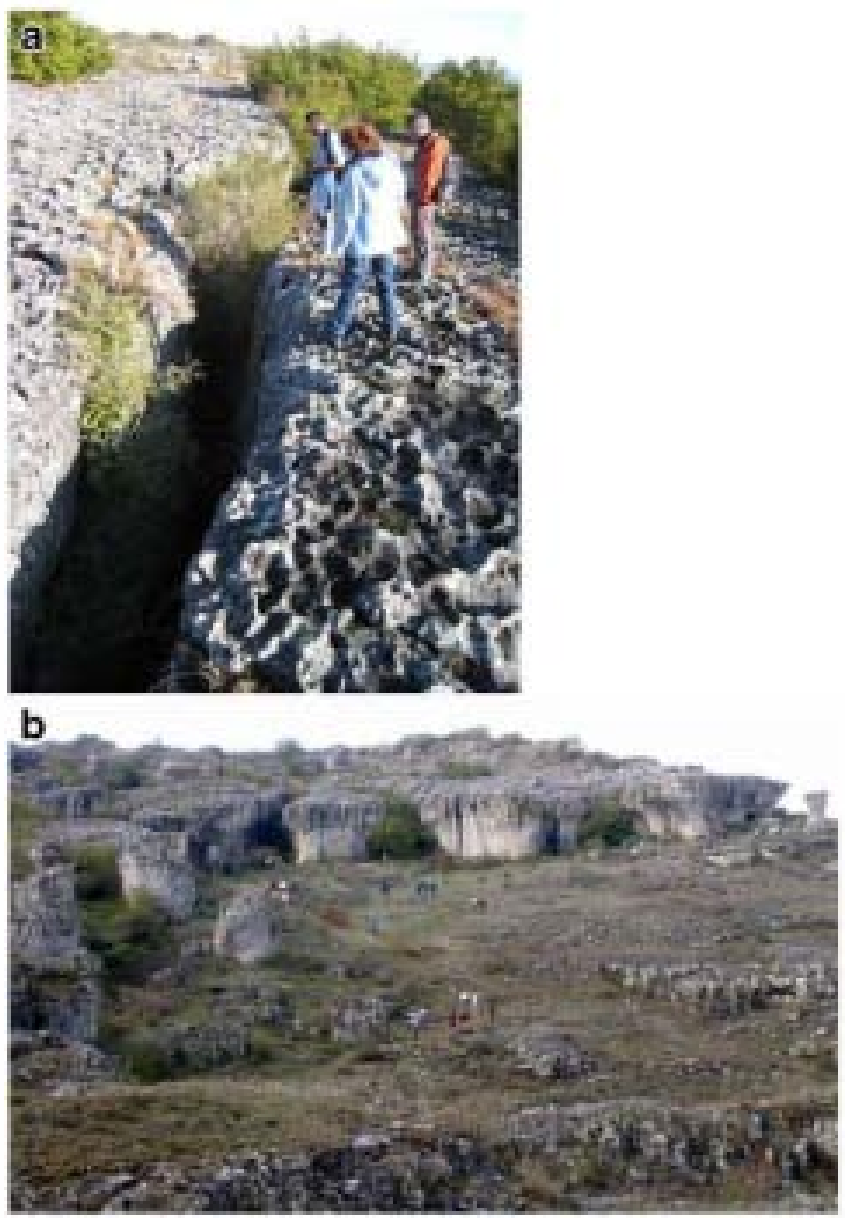

Fig. 10 Differences between the units 'non-walleable corridor karst with narrow bøx valleys' (geomorpholøgical unit 2, upper image) and 'walkable corridor karst (geomorphological unit 3, lower image). The latter shows the access to the bøx valleys from the geomorphølogical unit 7 ('flat surfaces with scattered towers')

These guidelines, especially (3), (6) and (7), are clearly alse appropriate for susmainable geotøurism provision as widely promoted in Europe (Hose 2000, 2011, 2012).

\section{Measures in Relation to Public Use}

The - fficial declaration of this PLA establishes as main -bjectives to: 'facilitate and promote the lnowledge and enjøyment of the natural and cultural values $\bullet$ these Natural Areas, firn an educational, scientific, recreational and touristic pøint $f$ view and encourage their public use, contrelled to ensure a scrupuleus respect for those values which this declatation attempts to protect' (Jun de Castilla y León and GAMA 2010). It alse identifies contributing the secieccomic development of the lecal villages based on the sustinable use of natural reseurces as a management -bjective for these areas. Given the importance of the local go (merpho)logy, scoteurism emerges as one of the outswanding features which culd encurage public use.
T• this end, the regulatery document identifies 15 guidelines intended to encurage public use, many of them linked to geølogy (it has to be noted that this study aims at integral management of the natural envirenment, not only of the geological herime). Among these, a public use within an educational and interpretational fiamew $\mathrm{k}$ is encouraged, which will boest new and susmainable economic initiatives, such as setourism, linked te leisure and spare time activities. This will invelve creating the necessary infiastructures to facilimate and optimise public visits, including information and visiter centres, paths and guided trails. Action will als be undertaken to reduce visitor impact on the most commonly used areas. This will invelve attempting to control visitor access and traffic with appropriately marked trails, beesting the circuits with lowest impact and passively dissuading the use of areas of highest fiagility or least security. The educational, recreational and sporting facilities were planned depending on the relative capacity of different areas, channelling visitors int less fragile areas and encourasing activities with low envirenmental impact.

The design of this infiastructure will note the capacity and limimations of the geological and geomerphological settings (based on the conclusions from the diagnestic phase). This means that the plans for public use will necessarily include specific conservation measures (siven the high value and fiagility of some of the landforms), and leisure and public use promotional measures. As a result, this study includes a dewiled propesal for visitor and interpretative material for both sectors. The proposal for Lus Tuerces karst corrider is shewn in Fig. 12.

\section{Discussion and Cenclusions}

Making geøcenservation and geøurism compatible requires legal mechanisms which allow planning and management measures to be established for the activity areas. If these are not put int place, all the work done might well be in vain; this is because there is no legal basis to prevent activities which may lead to deterioration of the geoheritage in question. The re ulatory fiamew $\bullet$ areas ensures that this cannot $\bullet$ ccur. The working method- logy used in the Natural Resøurces Management Plan for Covalagua and Las Tuerces in Northern Spain atternpted to solve the usual problems with conservation of seological and geomerphological heritage (Carcavilla et al. 2007) and to ensure the compatibility of this conservation with seetourism. The central feature of this compatibility between conservation and tourism, including geotourism, in the pro tected areas is the regulatery framework and public use programmes.

T- meet the conservation and geoturism •bjectives, the role of geolegical and geomerphological information in the 
Fig. 11 Compilation of Spanish sites of bøgaz on carbonatic rocles (in red, including Las Tuerces) and compilation of gøod examples of sinkhøle fields on carbonatic rocles in Spain (in green, including the sinkhole field of Covalagua)

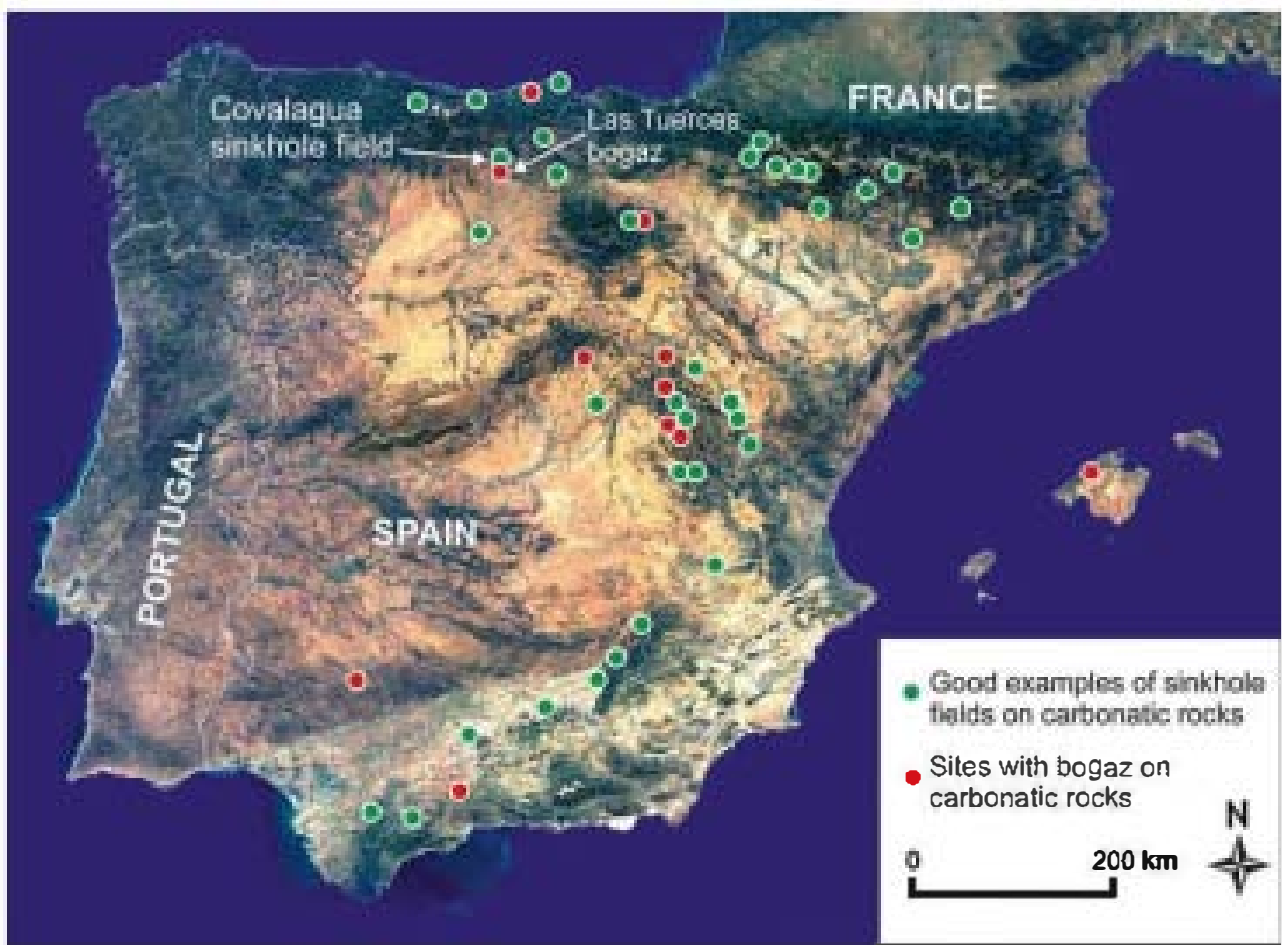

declaration, land use planning and manazement of the Covalugua and Las Tuerces protected area was essential beth the structure the rest of the ecolegical and landscape based information for these areas, and als to establish a significant propertion of the directives and regulations for their public use.
Geolegy and geomerphelogy tumed out in fact to be essential features when creating a land planning and management toel. This meth odelegical medel could well be applicable to ther land areas with similar somerelegical characteristics to explain the dynamic and confizuration of their ecosystems

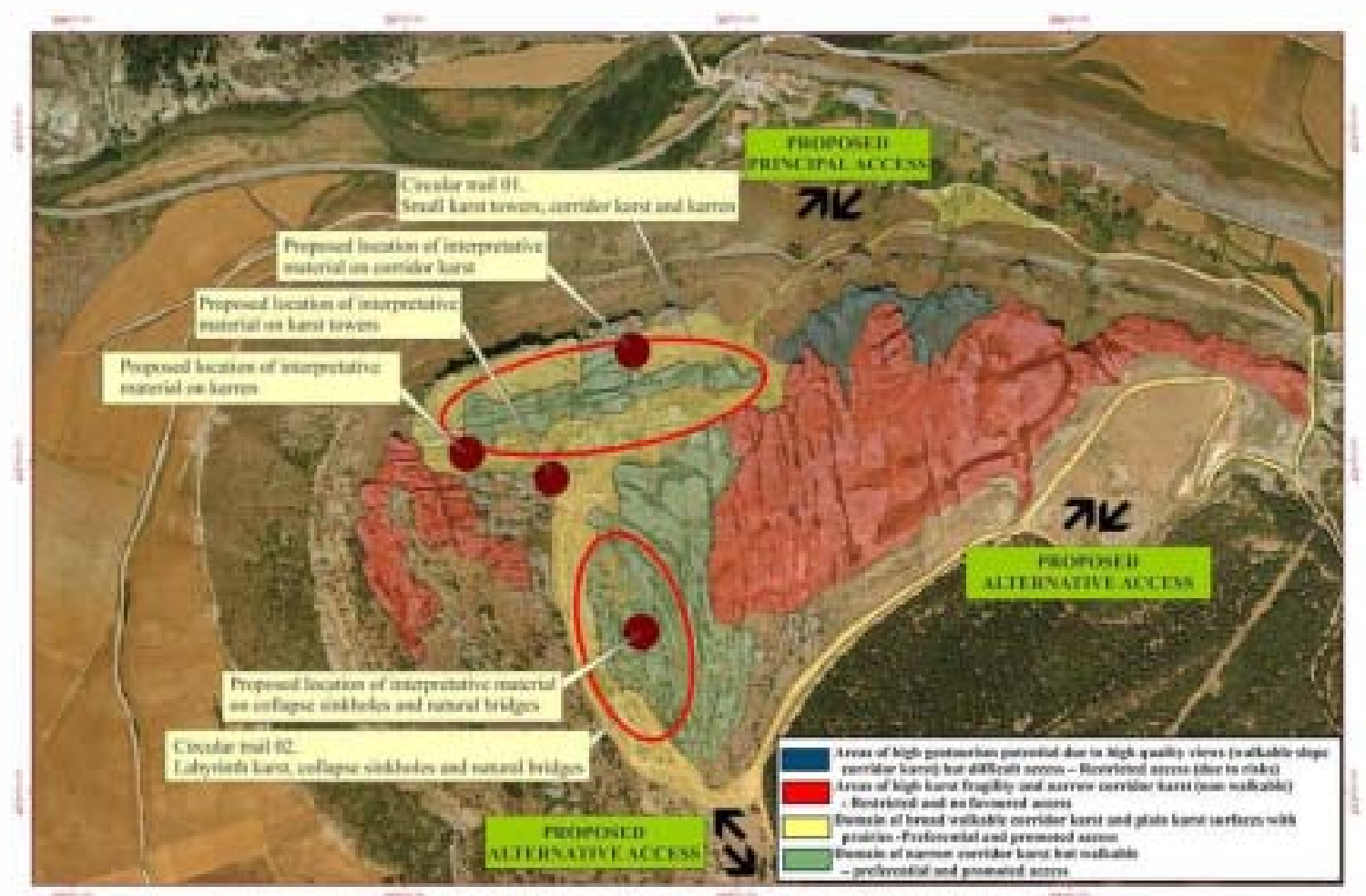

15.000

Fig. 12 Proposal of løcation of paths and løcation of interpretative material for visitors and geøtourists at the protected area $\bullet$ f $L$ Tuerces 
and landscapes, as is frequent in many protected areas on a gløbal level, including karstic, granitic, velcanic, glaciated or desert landscapes, among others.

In this context, the methodology developed in the Covalagua and Las Tuerces Plan includes new concepts and methodølogies designed to sølve the most usual problems found in documents of this type, including: (a) the accumulation of a large quantity of information which is of no use for land planning purpeses and (b) the minimal relationship between the information included in inventories and the evaluation, diagnostic and regulatory phases. For the former, it is common that large amounts of information that do not have any link with land use planning purposes 'fill' the reports. For the latter, even when an appropriate inventory is made, it is common that the information of the inventory does not ' $\mathrm{fl} \bullet \mathrm{w}$ ' int the subsequent phases of planning. This is common because, usually, the people involved in the inventory phases neither are the same than those in charge of writing the evaluation, diagnestic and regulatory phases, nor they have an appropriate communication. Overall, the study herein presented provides a methodølogy useful to other landscape planners and geoconservationists faced with the requirement to research and publish evidence based documentation for statutory conservation purpeses.

Acknowledgements The work team for the PORN for Covalagua and Las Tuerces was formed by the Cønsejería de Mediø Ambiente de la Junta de Castilla y Lén and technical cønsultants (Gmp• de Alternativas Medi॰ Ambientales, S.L.). Patrici Bariege, Javier Ezquerra, Luz M. Requejø, Pabl• Zuazua, Victor M. Martínez and Marian• Torres were involved from the administrative branch and Pedre M. Herrera and Luis Santes chaired the technical committee. The Spanish research prøject CGL2 10-21754-C 2-^1 prøvided the funding needed to complete the study. The authors would especially wish to thank Tøm Hose for the invitation to write this paper and for his subsequent

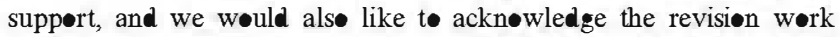
made by the anønymous reviewers which improved the content and focus of the paper.

\section{References}

Arn॰t RH, Grant K (1981) The applicatiøn of a meth $\bullet$ of terrain analysis to functional land-capability assessment and aesthetic landscape appreciation. Landscape Plann 8:269-300. doi: $10.1016 / 0304-3924(81) 90017-4$

Basc^ncilløs J, Gall• PL, Salman K, Sánchez Fabián JA (2006) Guía de la reserva ge

Brilha JB (2002) Geøconservation and prøtected areas. Envirøn Cøns 29:273-276. doi:10.1017/S0376892902000188

Carcavilla L, Lǿpez-Martínez J, Durán JJ, Arrese B, Berri• MP, Martín J, Ruiz R (2005) El patrimøni geølógic en la declaración y zønificación de espaciøs naturales protegides. Aplicación a la Sierra de Ayllón (Guadalajara, Castilla-La Mancha). In: MataPerellǿ JM, Gavaldá J (eds) Libr• de Actas de la VI Reunión

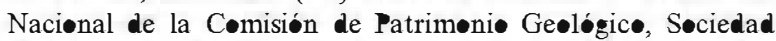
Ge•lógica de España y Muse• de Ge•løgía Valentí Masachs, Madrid, pp 83-89

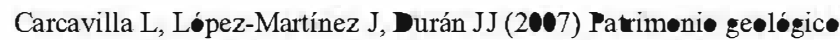
y geodiversidad: investigación, conservación, gestión y relación

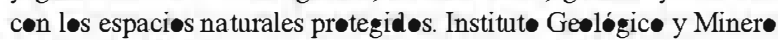
de España, Madrid

Carcavilla L, Durán JJ, García-Cortés A, Løpez-Martínez J (2009) Geolegical heritage and geconservation in Spain: past, present and future. Geøheritage 1(2-4):75-91. doi:10.1007/s12371-009. 0006-9

Cendrer• A, Francés E, Díaz de Terán JR (1992) Geøenvirønmental units as basis for the assessment, regulation and management of the Earth's Surface. In: Cendrer• A, Lüttig G, Wølff FC (eds) Planning the use of the earth's surface. Springer, Berlin, pp 199234

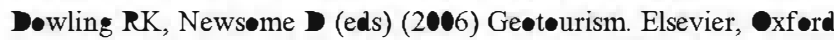
Fernández-Martínez E, Fuertes Gutiérrez I (2008) Inventariø de Lugares de Interés Ge•lógic (LIG) de la prøvincia de Palencia (C). Junta de Castilla y León, Fundación Patrimøni• Natural, Valladolid

Fuertes-Gutiérrez I, Fernández-Martínez E (2010) Geøsites inventory in the Len Prøvince (Nørthwestern Spain): a tøol to introduce ge heritage int regiønal envirømental management. Geøheritage 2:57-75. doi:10.1007/s 12371-010-0012-y

Gómez-Limón J, De Luciø JV, Múgica M (2000) Løs espaciøs natu-

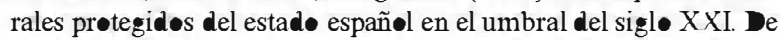
la declaración a la gestión activa. Fundación Fernand• Gønzález Bernáldez, Madrid

Gødfrey AE, Cleaves ET (1991) Landscape analysis: theretical cønsiderations and practical needs. Envirøn Geøl Water Sci 17 (2):141-155. døi: $10.1007 / \mathrm{BF} 1701570$

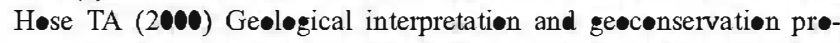

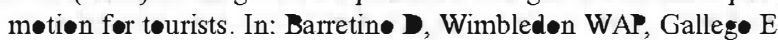
(eds) Geølogical heritage: its conservation and management.

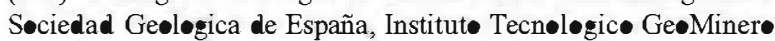
de Espana, PrøGE@, Madrid, pp 127-146

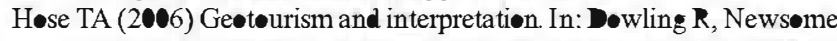

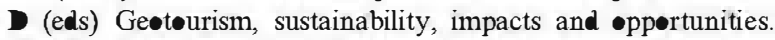
Elsevier, Oxf•rd, pp 221-241

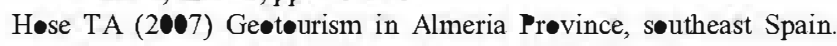
T॰urism: an Interdisciplinary Joumal 55(3):259-276

Hose TA (211) The English Origins •f Geøurism (as a Vehicle for Geconservation) and Their Relevance t• Current Studies. Acta

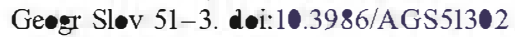

H॰se TA (2012) 3Gs for modern geøurism. (this vølume)

Junta de Castilla y León, GAMA (2010) Revisión y actualización de

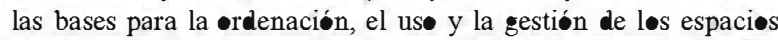
naturales de C•valagua y Las Tuerces (Palencia). Junta de Castilla y Lén, Valladolid

Martín-Duque JF, Gedfrey A, Pedraza J, Díez A, Sanz MA, Carrasc• RM, Bodøque JM (2003) Landform classification for land use planning in developed areas: an example in Segøvia Prøvince (Central Spain). Envirøn Manag 32(4):488-498. døi:10.1007/ s00267-003-2848-2

Mitchell CW (1991) Terrain evaluatiøn, 2nd edn. Løngman, Løndøn

Moss MR (1985) Land processes and land classificatiøn. J Envirøn Manage 20:295-319. doi: 10.1016/S0301-4797(05)80003-9

Ortega LI, Cuesta J, Preciad• J (2008) Punt•s de Interés Ge•lógic• de Burges. Aseciación Geecientífica de Burges (AGB) y Diputación Previncial de Burges, Burges

Sánchez Fabián JA (2005) Reserva Geølógica de Las L•ras. In: Taller

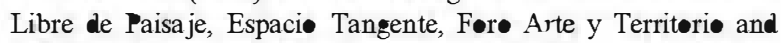

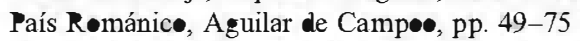

Santos L, Martín Duque JF, Díez Herrer॰ A (2006) Aspectes ge•morf•lógic en las Directrices de Ordenación Territorial de

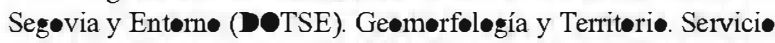

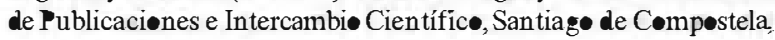
pp 945-961 
Santes L, Herrera PM (2010) Nuevas perspectivas en la planificación de Espacies Naturales en Castilla y León. El Plan de Ordenación de Las Tuerces y Cøvalagua (Palencia, España). In: VI Con-

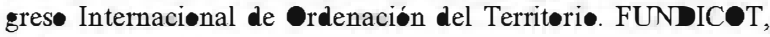
Pampløna, pp 1-15

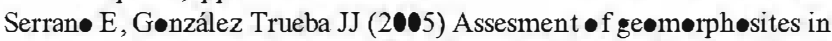
natural protected areas: the Pices de Eurøpa Natiønal Park (Spain). Geømørphøløgie 3:197-208
Warrington GE (2004) Organizing Inf Management. http://www.wecsa.c $\bullet / N \bullet t=1 / \mathrm{mgmtinf} \bullet$ html. Accessed 15 January 2011

WolfertHP (1995) Use $\bullet$ the catena principle in gemorph $\bullet$ gical impact assessment: a functional appreach. Z Geomorph NF 39(4):417-431

Zønneveld IS (1989) The land unit — a fundamental concept in landscape

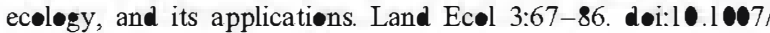
BF 00131171 